COMISSION 38: EXCHANGE OF ASTRONOMERS - (EQIANGE DES ASTRONOMES)

Committee of the Executive Committee

Report of Meeting on November 21, 1985

PIESSIDENT: F.B. WOOD

SECRETARY: F.G. SMITH

\title{
Officers and Organizing Committee
}

The Commission agreed that the Vice-President, Proi. E.A. Miller should become President for the next term of office, and proposed Pro:. F.G. Smith as new Vicepresident. It was also agreed that retiring iresidents would normally serve ex officio for three years on the Organizing Committee, and other members of the OC would normally serve for six years. Consequently, the following members retire now from the OC: J. Delhaye, D.A. MacRae, P.M. Routly, all former Presidents of the Commission. Furthermore K. Sahade, being proposed for President of the Union, retires for the time being from the OC of the Commission. To replace them the following persons were proposed for membership in the OC: A. Florsch (France), Y. Kozai (Japan), K. Ch. Leung (USA), and G. Swarup (India) .

Some changes in the regular Commission membership were also proposed.

Consequently, the following slate of officers and members for 1985-1988 was proposed by the Commission for ratification at the second session of the XIX General Assembly:

President: E.A. Müller

Rennweg 15

CH-4052 Base1

Switzerland

Vice-President: F.G. Smith

NRAL

Jodre11 Bank

Macclesfield

Cheshire SKII 9DL

U.K.

Organizing Committee: A.A. Boyarchuk, A. Florsch, Y. Kozai, K. Ch. Leung, G. Swarup, C.R. Tolbert, H.H. Voigt, F.B. Wood (ex officio), Ye Shu-Hua.

Neniers:

A.A. Al-Sabti, J. Delhaye, G. Codoli, H. Haupt, E. van den Heuve1, D. MacRae, M. Marik, S. Nin-kovic, I1-Seong Nha, S. Okoye, A. Opolski, A. Reiz, P.M. Routly, G. Ruben, J. Sahade, E.V.P. Smith, J.P. Wild.

Guidelines for the Travel Grant Scheme

The guidelines were discussed and it was suggested that more enphasis should be placed on the need to use the lowest possible air fares. Thus, in item (5) of the guidelines the first sentence was changed to read as follows: 
"The amount of the grant will be governed by the cost of a single return economy air fare, and limited to the least expensive fare such as PEX, APEX, etc.) between the home and host institutions and nomally is to be used by the applicant for such travel."

No other changes in the guidelines were proposed. The complete text of the guidelines and the application procedure will be published in the IAU information Bulletin No. 55,1986 .

Joint Meeting of Commissions 5,38 and 46

The President mention d that Commission 5 wished to have a joint meeting with Commissions 38 and 46 on "Documentation for Developing Countries", the meeting tn take place on November 25, 1985. Commission 38 will attend as an observer only, since it deals exclusively with travel grants and these are not restricted to developing countries only. Commission 5 will report on the joint meeting. 